boy of average height during a current survey; the fact remains that this boy was of average height at the time of our survey. Had we concentrated on boys of above average height (as is often the case in studies involving XYY individuals), this boy would not have been spotted.

(2) As our survey is still in progress we deliberately did not extrapolate his height for two reasons: (a) the boy is still under observation and we are hoping to be able to follow his growth as long as possible; (b) we supplied the two measurements in our paper to enable interested readers to do their own extrapolating.-We are, etc.,

Institute of Psychiatry,

J. KAHN London S.E.5

Reed International Ltd.

T. Contes

Larkfield, Kent

\section{Starch Granulomatosis of the Peritoneum}

SIR,-I was interested to read the article by Mr. Julian Neely and Dr. J. Douglas Davies (11 September, p. 625) on starch granulomatosis of the peritoneum and agree that this condition is much more common than is generally realized. I have seen two such cases during the last year. The first was found to have multiple peritoneal nodules at laporotomy after a previous resection of colon. The second was an incidental finding on the surface of an oophorectomy specimen, this patient having had a laparotomy some months before.

While the diagnosis, once thought of, is easy to make in those cases in which there are well marked granulomata with giant cells incorporating starch grains, this is not always so. There is considerable difficulty in distinguishing between contamination of preexisting adhesions and true starch-induced granulomata. Contamination by glove powder of routine biopsy material is very common In a series of 100 appendices and 200 fallopian tubes that Dr. Laverty and I have been studying we found contamination in $86 \%$. We believe this to have occurred at operation as the starch is often enmeshed within fibrin, but the possibility of the contamination from the pathologist's gloves during the "cut up" of specimens should be remembered.

During our study of these cases we have come across several lesions in previously non-operated patients (both male and female) which we believe to resemble those that others $^{1}$ have described as starch granu-

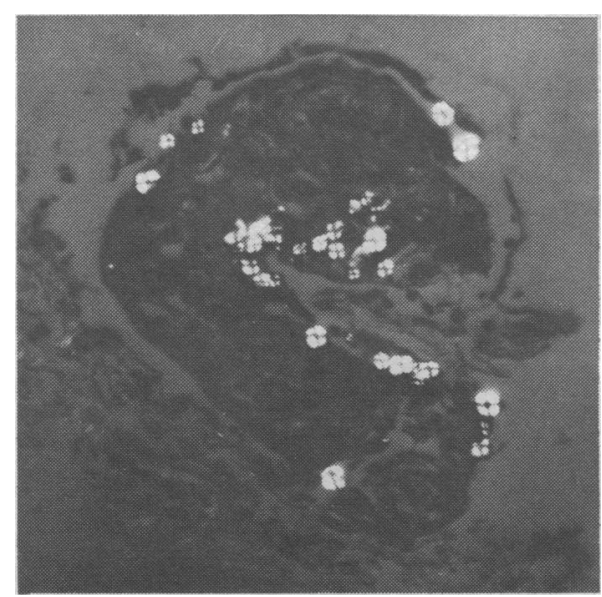

lomata. These consisted of inflammatory cells, mostly mononuclear, in a fibrous or fibrinous background with starch granules showing under polarized light. No giant cells were present. An example is shown in the Figure taken under polarized light. With the aid of collagen and fibrin stains one can see that this is not a starch granuloma but a folded fibrous adhesion with fibrin enmeshed starch granules on its surface.

Except in those cases such as Mr. Neely and Dr. Davies have described, in which there are clear foreign body giant cells with starch granules, care should be taken in ascribing granulomatous lesions in patients who have had previous surgery to starch glove powder rather than infection or surgical trauma.-I am, etc.

Department of Pathology,

G. R. SWINGLER

St. Mary's Hospital,

Manchester

1 Paine, C. G., and Smith, P., fournal of Clinical Pathology, 1957, 10, 51.

\section{Nitroprusside Revisited}

SIR,-Though we agree that sodium nitroprusside is a simple, speedy, and effective hypotensive agent, especially of value when other agents have failed, we do not think it is necessarily as innocuous as Dr. M. K. Mani claims (14 August, p. 407).

We have investigated the degradation of nitroprusside both in vivo and in vitro and have shown that the formation of cyanide and thence thiocyanate from nitroprusside occurs more quickly than earlier studies using less sensitive techniques suggested. ${ }^{1}$ Even though the pharmacological effects of nitroprusside may not be due to cyanide per se, the release of cyanide may constitute a hazard to certain patients who are especially vulnerable to its effects-namely, $B_{12}$-deficient, ${ }^{3}$ those with hereditary optic atrophy, ${ }^{45}$ and the malnourished. 6

The results of our studies will be published shortly.-We are, etc.,

J. WILSON

M.R.C. Clinical Genetics Research Uni Institute of Child Health and Institute of Neurology, London W.C.1

M.R.C. Clinical Genetics Research Unit, C. J. VeSEY National Hospital,

St. Bartholomew's Hospital,

P. V. Cole

1 Hill, H. E., Australian Chemical Institute fournal and Proceedings, 1942, 9, 89.

Page, I. H., Corcoran, A. C., Dustan, H. P., and Koppanyi, T., Circulation, 1955, 11, 188.
Wilson, J., and Langman, M. J.' S., Nature (London), 1966, 212, 787.

Wilson, J., Clinical Science, 1965, 29, 505. 5 Wilson, J., Linnell, J. C., and Matthews, D. M.,

6 Monekosso, G. L., and Wilson, J., Lancet, 1966, $1,1062$.

Osuntokun, B. O., Monekosso, G. L., and Wilson, J., British Medical foumal, 1969, 1 ,

\section{Predicting Fetal Maturity}

SIR,-It would be a pity if the conclusions of Miss Rosemary A. Underhill and others (25 September, p. 736) led readers to conclude that useful estimates of the length of gestation cannot be made from examination of amniotic fluid.

They based their conclusions on the appearance of amniotic fluid cells stained with
Nile blue sulphate and "in some samples" also on the determination of creatinine by an unspecified method for which a paper from this unit ${ }^{1}$ is quoted as a basis. We have subsequently pointed out ${ }^{2}$ that the laboratory method of measuring creatinine is of considerable importance; and while staining with Nile blue sulphate, introduced by Kittrich in $1963,{ }^{3}$ was an important historical landmark, it is now generally recognized as of no value to precise diagnosis.

We recently described a scoring system based on the appearance of cells stained with haematoxylin and eosin or with Papanicolaou's stain, and the "true" creatinine and urea contents of amniotic fluid and maternal plasma.4 This system enabled length of gestation to be predicted with an accuracy that is certainly of clinical value. Comparisons are difficult since Miss Underhill and colleagues predicted the expected date of confinement (E.D.C.) in cases of unknown gestational age, whereas we estimated length of gestation. It would seem, however, that our scoring system gives results at least as useful as those reported for ultrasound; moreover it can be used with a single sample taken at any time after 30 weeks' gestation and does not need sophisticated equipment.

And it is perhaps relevant to ask whether a predicted E.D.C. is what the obstetrician wants to know. Is it helpful, for example, in deciding whether or not to deliver a woman, to know that she would deliver normally in eight weeks? Is she eight weeks from 38 weeks or 42 weeks? It makes a difference. -I am, etc.,

T. LIND

M.R.C. Reproduction and Growth Unit, Princess Mary Maternity Hospital, Newcastle upon Tyne

1 Lind, T., Parkin, F. M., and Cheyne, G. A fournal of Obstetrics and Gynaecology of the

2 Lind, T., Billewicz, W. Z., and Cheyne, G. A., Fournal of Obstetrics and Gynaecology of the British Commonwealth, 1971, 78. 505.

Kirtrich, M., Geburtshilfe und Frauenheilkunde, Lind, T and Billewicz, W. Z., British fournal of Hospital Medicine, 1971, 5, 681.

\section{Bullous Lesions in Poisoning}

SIR,-I was interested to read Dr. C. $M$. Ridley's recent report (3 July, p. 28) and the subsequent correspondence ( 7 August, pp. $371,372)$. In my original paper ${ }^{1}$ we merely stated that these blisters were "sufficiently characteristic to suggest strongly the possibility of barbiturate poisoning." Carbon monoxide had been previously implicated and since then a number of other drugs (methadone, hydrocodone bitartrate, meprobamate, imipramine, and glutethemide) have occasionally been reported as causing blisters. It is still the experience, however, of the Regional Poisoning Treatment Centre, the Royal Infirmary, Edinburgh, with over 1,000 admissions annually, that the drugs which most frequently produce blisters are the barbiturates despite the declining incidence of overdosage from this drug (H. J. S. Matthew, personal communication).

The mode of production of these fascinating blisters in drug-induced coma is still open to speculation, as I indicated in a recent review on the skin in acute barbiturate poisoning. ${ }^{2}$ While I would agree that pressure and possibly hypoxia owing to circulatory changes are factors in the production of these blisters, I do not think as 
was suggested by Dr. C. M. Ridley (3 July, p. 28) and Sir Herbert Seddon and Mr. A. J. D. Howse (7 August, p. 371) that these can be the sole cause of the blisters. Most authors have noted that they do not occur necessarily over maximum pressure areas and the area marked by a query illustrates this well in the letter from Sir Herber Seddon and Mr. A. J. D. Howse. The marked epidermal necrosis and more recently reported eccrine sweat gland necrosis ${ }^{3}$ with little dermal damage are not features of pressure sores. In view of this I think we should not forget that it may be that the drugs may cause damage to the skin because of a direct effect on epidermal metabolism and not simply because they produce coma.

In summary, therefore, I think that a combination of coma, pressure, and certain drugs are all necessary before the type of blister we have been discussing develops.-I am, etc.,

G. W. BEVERIDGE

Department of Dermatology,

Royal Infirmary

1 Beveridge, G. W., and Lawson, A. A. H., British Medical foumal, 1965, 1, 835.

2 Beveridge, G. W., in Acute Barbiturate Poisoning, ed. H. J. S. Matthew, p. 129. Amsterdam Excerpta Medica, 1971 3 Leavell, U. W., Archives of Dermatology, 1969

\section{Junior Staff and Private Patients}

SIR,-In view of Dr. D. R. Redman's letter from this department (2 October, p. 51), which I have just seen, I feel that I owe it to my colleagues to state that members of the staff of this department do not undertake private work.

Dr. Redman has confirmed to me that his remarks do not relate to Edinburgh.-I am etc.,

RONALD H. GIRDWOOD

Department of Therapeutics,

Royal Infirmary,

Edinburgh

\section{Liver Disease in Japan}

SIR,-As previously reported, 1 the mortality rate from cirrhosis in Japan is high, and viral hepatitis as an aetiological agent appears to be commoner than in other countries Hepatitis-associated antigen (H.A.A.) was therefore sought by the method of counterimmunoelectrophoresis in 712 patients with liver disease in Osaka, Japan.

In 147 patients with acute hepatitis 32 $(21.7 \%)$ were found to have H.A.A. Amon these $20(22.7 \%)$ of 88 patients with infectious hepatitis and $12(21 \%)$ of 57 cases of serum hepatitis were positive, findings which support the view of others 3 that sporadic infection occurs with the virus of serum hepatitis. Forty-six (12.8\%) of 358 patients with chronic hepatitis had H.A.A. One hundred and fourteen had chronic active hepatitis on liver biopsy and $34(29.8 \%)$ were positive, while 81 were thought to be inactive and only four $(4.9 \%)$ had positive H.A.A. tests. The higher frequency associated with activity of the disease, similar to that reported by Prince, suggests that H.A. antigenaemia may play an important role in the development of chronic hepatic disease.

Only nine (7.2\%) of 124 patients with cirrhosis had detectable H.A.A. In all patients with alcoholic cirrhosis, fatty liver, and constitutional jaundice the test was negaive. Two of our patients with idiopathic portal hypertension and four of 39 with extrahepatic obstructive jaundice had positive tests for H.A.A.-We are, etc.,

T. KoIzumi

T. KAMADA

T. AKIYAMA

Department of Medicine,

rsity Hospital,

Osaka, Japan

Yoshida, T., et al., Acta Hepato-splenologica Krugman, S., and Giles, J. P., fournal of the American Medical Association, $1970,212,1019$ Prince, A. M., et al., New England fournal of Medicine, 1970, 282, 987 .

Prince, A. M., Leblanc, L., Krohn, K., Masseyeff, R., and Alpert, M. E., Lancet, 1970, 2, 717

\section{Shortage of Technicians}

SIR,-Dr. J. O'H. Tobin and others (4 September, p. 584) wish for justification for the post of principal technician. If, as they say, "it may well in practice entail only administrative duties quite capable of being done by a more junior person," and "the use of a person with high technical expertise for such duties is not value for salary, and is unlikely to further the skills on which the efficiency and development of a laboratory ultimately depends," then, they have a principal technician in name only.

Laboratories (theirs included apparently) have largely been administered by the typical pathologist-chief technician relationship established over many years. The pathologist was responsible for laboratory policy and the chief technician for the technical running of the laboratory complex. As laboratories increased in size, so the administrative duties of the chief technician increased to the point where clerical assistance was necessary to release the chief technician from such duties. The administration has not seen fit to provide such clerical assistance and so many chief technicians have degenerated into well-paid junior administrators.

The role which should have been allowed to develop in a rapidly expanding laboratory complex is that of technical manager. This is a sphere which is more likely to furthe the skills on which the efficiency and development of a laboratory ultimately depends. Dare I again quote Sir Keith Joseph in the use of the words, "effective management," for effective management at the level of expenditure incurred by laboratories must surely result in benefits to both the service and the budget. In terms of resource and recruitment the value of good management takes on an exponential curve, though I realize that this is not the end of the problem.

Some pathologists and chief technicians have not yet reached 1970 standards of management. The image of the chief technician as a man in a white coat who walks around with his hands in his pockets asking, "Is everything all right?" still exists in some laboratories. This is not always the fault of the pathologist, though a change of attitude on his part still appears to be the most influential factor in deciding the managerial content of the principal technician's job. suppose that dithyrambic rumblings from principal technicians are to be expected, but nevertheless there is a place for them in the laboratory management outside administrative duties, and if they do not accept it, then they are unworthy of the title.-I am, etc.,

J. B. BuRns

West Cardiff Area Laboratory

Cardiff

Faculty of Community Medicine

SIR,-The Report of the Royal Commission on Medical Education (1965-68) 1 recommended that an organization should be formed which would have a major role in the training of those who practise in the field of community medicine.

A working party, composed of representatives of the Royal College of Physicians of London, the Royal College of Physicians of Edinburgh, and the Royal College of Physicians and Surgeons of Glasgow and of doctors drawn from the Society of Medical Officers of Health and its Scottish branch, the senior administrative medical officers of the regional hospital boards in England and the Welsh Hospital Board, the Society for Social Medicine, the Scottish Association of Medical Administrators, medical members of the staffs of the Department of Health and Social Security and the Scottish Home and Health Department, has been meeting over the last twelve months. As the result of these meetings the working party has recommended to the colleges that they should combine in the formation of a faculty of community medicine which will be part of their own structure.

Community medicine is that branch of medicine which deals with populations or groups rather than with individual patients. In the context of a national system of medical care, it, therefore, comprises those doctors who try to measure accurately the needs of the population, both sick and well. It will require to bring to this study special knowledge of the principles of epidemiology of the organization and evaluation of medical care systems, of the medical aspects of the administration of health services, and of the techniques of health education and rehabilitation which are comprised within the field of social and preventive medicine. Community medicine thus brings together within the one discipline those who are presently engaged in the practice of public health, in the administration of the health service whether in hospital, local authority, or central government in relevant research, and those responsible for undergraduate and postgraduate education in the university departments of social medicine.

It is hoped that the inaugural meeting of the faculty will take place in March 1972 and we would like, with your permission, to draw attention to the invitation, which appears on $\mathrm{p}$. li, to those eligible to apply for foundation membership of the faculty.We are, etc.

J. Halliday Croom
Royal College of Physicians of Edinburgh

E. M. McGIRR

Royal College of Physicians and Surgeons of Glasgow

ROSENHEIM President,
Royal College of Physicians of London

ndon N.W.1 Royal Commission on Medical Education. Report
$1965-68$, Cmnd. 3569. London, H.M. S. O 1968 . 